\title{
Amino acid infusion in oligohydromnios and increase in AFI and impact on perinatal outcome
}

\author{
Isha Sunil, Chejerla Sunitha*, Harkirat Kaur
}

Department of Obstetrics and Gynecology, Acharya Shri Chander College of Medical Sciences, Jammu, Jammu and Kashmir, India

Received: 03 December 2018

Accepted: 29 December 2018

*Correspondence:

Dr. Chejerla Sunitha,

E-mail: c_sunita2002@yahoo.co.in

Copyright: () the author(s), publisher and licensee Medip Academy. This is an open-access article distributed under the terms of the Creative Commons Attribution Non-Commercial License, which permits unrestricted non-commercial use, distribution, and reproduction in any medium, provided the original work is properly cited.

\begin{abstract}
Background: Decreased amniotic fluid is related to adverse maternal and perinatal outcomes. The purpose of this study was to evaluate the role of amino acid infusion in patients of oligohydromnios and compare the perinatal outcome in the two groups.

Methods: This study was conducted in the Department of Obstetrics and Gynaecology, ASCOMS Hospital, Jammu for a period of one year from October 2017 to September 2018. A total of 50 women with AFI $<8 \mathrm{~cm}$ were enrolled in the study. They were divided into two groups of 25 each. Group A were given amino acid infusion and Group B were not given any intervention. These were compared for increase in AFI and perinatal outcome.

Results: In the present study, the gain in AFI in Group A was $2.32 \pm 0.67$ and in group B was $1.32 \pm 1.03$ which was statistically significant. The perinatal outcome was better Group A compared to Group B with decreased incidence of meconium stained liquor, low birth weight, low APGAR scores and NICU admissions and increase in vaginal deliveries as compared to caesarean sections.

Conclusions: The present study suggests that parentral transfusion of amino acid in cases of oligohydromnios significantly increases the AFI of the patient and decreases the incidence of caesarean sections, meconium stained liquor, low APGAR scores and NICU admissions.
\end{abstract}

Keywords: AFI, Amino acid infusion, Oligohydromnios

\section{INTRODUCTION}

Amniotic fluid provides a protective milieu for the growing foetus. It cushions the foetus against mechanical and biological injury, supplies nutrients to it and facilitates its growth and movement. The quantity of amniotic fluid increases from $25 \mathrm{ml}$ at 10 weeks to about $400 \mathrm{ml}$ at 20 weeks.

It further increases to about $800-1000 \mathrm{ml}$ at 28 weeks, plateaus near term and declines to about $400 \mathrm{ml}$ at 42 weeks. ${ }^{1}$ There are various ultrasound techniques for the measurement of amniotic fluid which include single deepest vertical pocket, two-diameter pocket, and amniotic fluid index. Amniotic flu-id index (AFI) was proposed by Phelan as an objective and more reproducible method of measuring amniotic fluid. The uterus is arbitrarily divided into 4 quadrants at the level of umbilicus and lineanigra.

The largest pocket in each quadrant free of foetal parts and cord are measured and add-ed to give the value of AFI. An AFI of $5-18 \mathrm{~cm}$ is considered normal. ${ }^{2}$

Oligohydromnios has been defined as less than 3rd and 5 th percentile of the normal value of AFI. Phelan had described amniotic fluid index defined oligohydromnios as an AFI less than $5 \mathrm{~cm}^{2}$, but later Jeng et al proposed cut-off of $8 \mathrm{~cm}$ demonstrating increased incidence of meconium staining, caesarean delivery for foetal distress, 
abnormal foetal heart rate pattern and Apgar scores of 7 or less at one minute when AFI was less than $8 .^{3}$ In this study we have considered AFI of 8 as cut off for diagnosis of oligohydromnios.

The reported incidence of oligohydromnios varies between 0.5 to $>5 \%$, depending on the definition of the oligohydromnios used and the population studied. ${ }^{4}$ Maternal conditions associated with de-creased amniotic fluid volume include post-dated pregnancy, preterm premature rupture of mem-branes, hypertension, autoimmune disorders, and maternal medications like prostaglandin synthesise inhibitors.

Foetal factors leading to oligohydromnios are intrauterine growth restriction and foetal anomalies, particularly of renal tract like bilateral renal genesis, multi cystic dysplastic kidneys, polycystic kidney disease and bladder outlet obstruction.

Oligohydromnios is linked to increased perinatal morbidity and mortality. Foetal deformities like potter faces (i.e. flattened nose, prominent epicentral folds and low set ears) are seen in patients of oligohydromnios. Studies have seen increased association of meconium stained liquor, still birth and neonatal and perinatal mortality with decreased liquor. ${ }^{5}$

Amino acid infusion is often prescribed for the treatment of oligohydromnios. Amino acids constitute the carbon and nitrogen requirement for the placenta and foetus. Amino acid acts as regulators of the development of the foetus and placenta.

They are a source of protein building blocks in the foetus and they also influence metabolic cyclic pathways between placenta and foetus. These are shown to improve vascularity through nitric oxide and also stimulate insulin secretion leading to foetal growth. ${ }^{6}$

Also, in growth restricted foetuses, the serum amino acids were found lower than those in normally grown foetuses. Based on this fact, there has been a renewed interest to prevent and treat IUGR and oligohydromnios by maternal amino acid supplementation and hyper alimentation.

\section{METHODS}

This study was conducted in the Department of Gynaecology and Obstetrics in Acharya Shri Chan-der College of Medical Sciences from October 2017 to September 2018. The study comprised of 50 clinically and sonographically proven cases of oligohydromnios in their third trimester.

\section{Inclusion criteria}

- $\quad$ Singleton pregnancy

- $\mathrm{AFI}<8$

- Gestational age 28-40 weeks.

\section{Exclusion criteria}

- Multifoetal gestation

- Associated foetal congenital abnormalities

- Premature rupture of membranes.

The patients were divided into Group A and Group B of 25 patients each. Group A subjects were given alanine $200 \mathrm{ml}$ on alternate days for 3 doses and Group B patients were not given any intervention.

The patients were evaluated for the following parameters:

- Gain in AFI

- Perinatal outcome which includes:

- Mode of delivery

- Incidence of meconium stained liquor

- Foetal weight

- Apgar score at 1 and $5 \mathrm{~min}$

- NICU admission.

The results were recorded and tabulated. The data was analysed using student's t-test and Chi- square test.

\section{RESULTS}

Mean age of Group A was 27.24 \pm 3.81 years and mean age of Group B was 26.48 $\$ 3.60$ years, which was comparable $(\mathrm{p}=0.4720)$ (Table 1$)$.

Table 1: Distribution of patients according to age.

\begin{tabular}{|l|l|l|}
\hline Age (years) & Group A no. & Group B no. \\
\hline $15-19$ & 0 & 0 \\
\hline $20-24$ & 7 & 6 \\
\hline $25-29$ & 11 & 15 \\
\hline $30-34$ & 6 & 4 \\
\hline $35-39$ & 1 & 0 \\
\hline total & 25 & 25 \\
\hline Mean \pm SD (years) & $27.24 \pm 3.81$ & $26.48 \pm 3.60$ \\
\hline Statistical inference & $\begin{array}{l}\text { Unpaired t value=0.7249; } \\
\text { p=0.4720; not significant }\end{array}$ \\
\hline
\end{tabular}

Forty \% of patients in Group A and 38\% in Group B were primigravidae, while $60 \%$ of patients in Group A and $60 \%$ in Group B were multigravidae; both groups being statistically comparable $(\mathrm{p}=1.00)$ (Table 2$)$.

Table 2: Gravidity of patients.

\begin{tabular}{|l|l|l|l|}
\hline Gravidity & $\begin{array}{l}\text { Group a } \\
\text { no. }(\%)\end{array}$ & $\begin{array}{l}\text { Group b } \\
\text { no. }(\%)\end{array}$ & $\begin{array}{l}\text { Statistical } \\
\text { inference }\end{array}$ \\
\hline Primigravida & $10(40)$ & $10(40)$ & $\begin{array}{l}\text { Chi } \\
\text { square=0.00 }\end{array}$ \\
\hline Multigravida & $15(60)$ & $15(60)$ & $\begin{array}{l}15=1.00 ; \text { Not } \\
\text { significant }\end{array}$ \\
\hline Total & $25(100.00)$ & $25(100.00)$ \\
\hline
\end{tabular}

The mean gestational age for group A was 31.2 \pm 2.12 and that of group B was $30.96 \pm 1.69$; which was statistically 
non-significant (Table 3). Mean value of AFI in group A was $5.1 \pm 1.35$ and that of group B was $5.04 \pm 1.53$; the difference being statistically non-significant (Table 4).

Table 3: Gestational age of the patients.

\begin{tabular}{|l|l|l|}
\hline Gestational age & $\begin{array}{l}\text { Group A No. } \\
(\%)\end{array}$ & $\begin{array}{l}\text { Group B No. } \\
(\%)\end{array}$ \\
\hline 28-32 weeks & $15(60.00)$ & $14(56.00)$ \\
\hline 32-36 weeks & $10(40.00)$ & $11(44.00)$ \\
\hline 36 weeks onwards & $00(00.00)$ & $00(00.00)$ \\
\hline Mean GA (weeks) & $31.2 \pm 2.12$ & $30.96 \pm 1.69$ \\
\hline Statistical inference & $\begin{array}{l}\text { Unpaired t test value=0.442; } \\
\mathrm{p}=0.66 ; \text { Not significant }\end{array}$ \\
\hline
\end{tabular}

Table 4: AFI of the patients.

\begin{tabular}{|l|l|l|}
\hline AFI & $\begin{array}{l}\text { Group A } \\
\text { No. }(\%)\end{array}$ & $\begin{array}{l}\text { Group B } \\
\text { No. (\%) }\end{array}$ \\
\hline $\begin{array}{l}\text { 5-8 (moderate } \\
\text { oligohydromnios) }\end{array}$ & $15(60.00)$ & $11(44.00)$ \\
\hline$<5($ severe oligohydromnios) & $10(40.00)$ & $14(56.00)$ \\
\hline Mean AFI (cm) & $\begin{array}{l}5.1 \pm 1.35 \\
\text { Unpaired t test } \\
\text { value=0.147; }=0.88 ; \text { not } \\
\text { significant }\end{array}$ \\
\hline Statistical inference & \\
\hline
\end{tabular}

Table 5 depicts the gain in AFI in the two groups. The gain in AFI in Group A was 2.32 \pm 0.67 and in group B was $1.32 \pm 1.03$. This difference was statistically significant with a p-value of $<0.0001$.

Table 5: Gain in AFI.

\begin{tabular}{l|l|l|} 
Gain in AFI & Group A & Group B \\
Average gain in AFI & $2.32 \pm 0.67$ & $1.32 \pm 1.03$ \\
Statistical inference & $\begin{array}{l}\text { Unpaired t test value=8.138; } \\
\mathrm{p}=<0.0001 ; \\
\text { significant }\end{array}$ \\
\hline
\end{tabular}

Thus, there was increased gain in in the group that received amino acid infusion than the group which did not. As shown in Table 6, there was increased incidence of caesarean section in Group B than Group A.

Table 6: Mode of delivery.

\begin{tabular}{|l|l|c|}
\hline Mode of delivery & Group A & Group B \\
\hline Normal vaginal delivery & $15(60.00)$ & $11(44.00)$ \\
\hline LSCS & $10(40.00)$ & $14(56.00)$ \\
\hline Statistical inference & $\begin{array}{l}\text { Chi-square } 0.721 \text { and p- } \\
\text { value 0.3958; statistically } \\
\text { non-significant }\end{array}$ \\
\hline
\end{tabular}

Chi square value was 0.721 with 1 degree of freedom. The two-tailed $\mathrm{P}$ value was 0.3958 . The as-sociation between the two groups is considered to be not statistically significant. Table 7 shows the incidence of adverse perinatal outcome in the two groups. The incidence of MSL in group A was $20 \%$ and $28 \%$ in group B. Low birth weight incidence was $24 \%$ in group A and $40 \%$ in group B.

Table 7: Incidence of adverse perinatal outcome.

\begin{tabular}{|l|l|l|}
\hline Adverse perinatal outcome & $\begin{array}{l}\text { Group A } \\
(\%)\end{array}$ & $\begin{array}{l}\text { Group B } \\
(\%)\end{array}$ \\
\hline Meconium stained liquor & $5(20)$ & $7(28)$ \\
\hline Low birth weight & $6(24)$ & $10(40)$ \\
\hline A/S <5 & $3(12)$ & $6(24)$ \\
\hline NICU admission & $4(16)$ & $7(28)$ \\
\hline
\end{tabular}

Low Apgar score $<5$ was in $12 \%$ in group A and $24 \%$ in group B. NICU admission incidence in Group A was $16 \%$ and $28 \%$ in group B.

\section{DISCUSSION}

Oligohydromnios is a sign of foetal malnutrition. Amniotic fluid infusion provides amino acids to the mother and improves her nutritional status as well as pregnancy outcomes. Various studies have tried intravenous infusion of large amounts of glucose and amino acids to the mothers. ${ }^{7}$ Pregnant patients with oligohydramnios have been infused with amino acids for improvement of foetal out-come. Mothers with IUGR foetuses have also been infused with $10 \%$ Fructodex and amino acid solutions. ${ }^{8}$ Improved maternal nutritional status by intravenous amino acid infusion appears to improve the AFI. This improvement may not have been achieved with diet alone because of non-compliance and socio- economic status. In the present study maximum number of cases in both the study and control group were in the age group of 25 to 29 years, with the average maternal age of $27.24 \pm 3.81$ years in the study group and $26.48 \pm 3.60$ years in the control group. Shivkumar PV et al in their study found that $78 \%$ cases were in the age group of 20-29 years and the mean maternal age was 22.8 \pm 4.2 years. ${ }^{9}$ Also, studies by Chauhan $P$ et al, Jun Zhang et al and Everett $F$ et al found that the mean maternal age were respectively $23.6 \pm 6.5$ years, $28.4 \pm 3.4$ years and $23.8 \pm 5.7$ years. ${ }^{10-12} 40 \%$ of patients in the study group and $38 \%$ in control group were primigravidae, while $60 \%$ of patients in the study group and $60 \%$ in the control group were multigravidae; both groups being statistically comparable $(\mathrm{p}=1.00)$.

Mean value of AFI in the study group was $5.1 \pm 1.35$ and that of control group was 5.04 \pm 1.53 ; the difference being statistically non-significant so that subjects in both the groups were comparable. The mean gestational age in the study group was $31.2 \pm 2.12$ weeks and in the control, group was $30.96 \pm 1.69$. Similar studies by Jun Zhang et al, Casey B et al, Everett F et al and Hoskins IA et al found that, the mean gestational age were 38.1 \pm 3.3 weeks, $37.5 \pm 2$ weeks, $34.3 \pm 2.1$ weeks, and (mean \pm SD) was $36.3 \pm 2$ weeks respectively. ${ }^{11-14}$ It was observed that there was significant difference in the gain in AFI in the groups who received amino acid infusion as compared to 
the control group as seen by a repeat ultrasound after a week. The gain in AFI in Group A was 2.32 \pm 0.67 and in group $\mathrm{B}$ was $1.32 \pm 1.03$. Ahmad $\mathrm{A}$ in his study also observed that intravenous infusion of large amount of amino acid and glucose appears to improve the AFI. ${ }^{15}$ According to Suzuki et al 10\% Maltose can be used as an intravenous solution for increasing the amniotic fluid volume and there was significant increase in AFI with one-week therapy. ${ }^{16}$ American pregnancy association also states that maternal intravenous infusion is known to increase amniotic fluid volume. ${ }^{17}$ The perinatal outcome was better in the group with amino acid infusion as compared the control group. The incidence of meconium stained liquor in study group was $20 \%$ and $28 \%$ in the control group. The incidence of low birth weight was observed to be was $24 \%$ in study group and as com-pared to $40 \%$ in the control group. Low Apgar score <5 was in $12 \%$ in study group and $24 \%$ in the control group. NICU admission incidence was also lower in study group as compared to the control group (16\% v/s 28\%). Among the mode of delivery, $60 \%$ of the patients in study group delivered vaginally as compared to $44 \%$ in the control group. Hebbar $\mathrm{S}$ et al in their study observed better perinatal outcome in the patients who received ami-no acid infusion in terms of lesser neonatal deaths and lesser number of NICU admissions. ${ }^{18}$ Gupta $\mathrm{R}$ et al in their study observed increase in vaginal deliveries and decrease in the number of neonatal deaths and decreased incidence of low APGAR scores at birth when patients of oligohydromnios were infused with amino acids. ${ }^{19}$

\section{CONCLUSION}

The present study suggests that parentral transfusion of amino acid in cases of oligohydromnios significantly increases the AFI of the patient and decreases the incidence of cesarean sections, meconium stained liquor, low APGAR scores and NICU admissions.

Funding: No funding sources Conflict of interest: None declared

Ethical approval: The study was approved by the Institutional Ethics Committee

\section{REFERENCES}

1. Underwood MA, Gilbert WM, Sherman MP. Amniotic fluid: not just foetal urine anymore. J Perinatol. 2005;25(5):341-48.

2. Phelan JP, Smith CV, Small M. Amniotic fluid volume assessment with the four-quadrant technique at 36-42 weeks' gestation. J Reprod Med 1987; 32(7):540-42.

3. Jeng CJ, Lee JF, Wang KG, Yang YC, Lan CC. Deceased amniotic fluid index in term pregnancy. Clinical significance. J retrod Med 1992;37(9):789-92.

4. Zhang J, Troendle J, Meikle S, Klebanoff MA, Rayburn WF. Isolated oligohydromnios is not associated with adverse perinatal outcomes. Br J Obstet Gynaecol. 2004;111(3):220-5.
5. Casey BM, Mclntire DD, Bloom SL, Lucas MJ, Santos R, Twickler DM et al. Pregnancy outcomes after antepartum diagnosis of oligohydromnios at or beyond 34 weeks' gestation. Am J Obster Gynaecol. 2000;182(4):909-12.

6. Awasthi A, Thakur R, Dave A. Maternal and perinatal outcome in cases of Moderate and severe anemia. J Obstet Gynecol India. 2001;51(6):62-65.

7. Krishna U. Pregnancy at risk current concepts, Jaypee Brothers Medical Publishers 1997,48,273-80.

8. Joshi V, Sapre S. Role of amino acid infusion in cases of Oligohydramnios in improving pregnancy outcome. J. Obstet Gynecol India. 2001;51(4):60-2.

9. Shivkumar PV, Tayade S, Tayade AT, Bagde ND, Bagde MN. The Role of Intravenous Hydration and Amino Infusion in Intrauterine Growth Restriction and Oligohydramnios. Int J Biol Med Res. 2011;2(4):107883.

10. Chauhan SP, Hendrix NW. Intrapartum oligohydramnios does not predict adverse peripartum outcome among high risk parturient. Am J Obstet Gynecol. 1997;176(6):1130-6.

11. Zhang J, Troendle J, Meikle S, Klebanoff MA, Rayburn WF. Isolated oligohydramnios is not associated with adverse perinatal outcomes. BJOG: An Int J Obstet Gynaecol. 2004;111(3):220-5.

12. Magann EF, Nolan TE, Hess LW, Martin RW, Whitworth NS, Morrison JC. Measurement of amniotic fluid volume: accuracy of ultrasonography techniques. Am J Obstet Gynecol. 1992;167(6):1533-7.

13. Casey BM, McIntire DD, Bloom SL, Lucas MJ, Santos R, Twickler DM et al. Pregnancy outcomes after antepartum diagnosis of oligohydramnios at or beyond 34 weeks' gestation. Am J Obstet Gynecol. 2000;182(4):909-12.

14. Hoskins IA, Friden FJ. Variable deceleration in reactive non-stress test with decreased amniotic fluid index predicts foetal compromises. Am J Obstet Gynecol. 1991;165(4):1094-8.

15. Ahmad A. Amino acid infusion in oligohydramnios; JK practitioner 2006;13(3);140-1.

16. Suzuki S, Mine K, Sawa R, Yoneyama Y, Araki T. $10 \%$ maltose infusion therapy for oligohydramnios. Aus New Zealand J Obstet Gynaecol. 1999;39(3):373-5.

17. Umber A, Chohan MA.JColl Physicians Surg Pak.2007;17(6):336-9.

18. Hebbar S, Rai L, Adiga P. Maternal hydration and Larginine supplementation improves liquor volume in patients with decreased liquor and prolongs pregnancy. Med J DY Patil Univ. 2014;7(4):429-34.

19. Gupta R, Porwal SK, Swarnkar M, Gupta S. The Role of Intravenous Amino Acid Infusion in Oligohydramnios. Int J Pharm Sci Res. 3(10); 3971-4.

Cite this article as: Sunil I, Sunitha C

Kaur H. Amino acid infusion in oligohydromnios and increase in AFI and impact on perinatal outcome. Int J Reprod Contracept Obstet Gynecol 2019;8:617-20. 